\title{
Protecting Food Cultural Biodiversity: From Theory to Practice. Challenging the Geographical Indications and the Slow Food Models
}

\author{
Mariagiulia Mariani $^{1, *(D)}$, François Casabianca ${ }^{2}$, Claire Cerdan $^{1}$ (D) and Iuri Peri $^{3}$ (D) \\ 1 CIRAD, UMR Innovation, 73, Rue François Breton, 34398 Montpellier, France; claire.cerdan@cirad.fr \\ 2 INRAE, UR LRDE, Quartier Grossetti, 20250 Corte, France; casabiancaf@wanadoo.fr \\ 3 Department of Agriculture, Food and Environment, University of Catania, DI3A, Via Santa Sofia 100, \\ 95123 Catania, Italy; peri@unict.it \\ * Correspondence: mariagiuliam@gmail.com
}

check for updates

Citation: Mariani, M.; Casabianca, F.; Cerdan, C.; Peri, I. Protecting Food Cultural Biodiversity: From Theory to Practice. Challenging the Geographical Indications and the Slow Food Models. Sustainability 2021, 13, 5265. https://doi.org/ $10.3390 /$ su13095265

Academic Editors: Giovanni Belletti, Andrea Marescotti, Filippo Arfini,

François Casabianca,

Emilie Vandecandelaere and

Junko Kimura

Received: 15 March 2021

Accepted: 5 May 2021

Published: 8 May 2021

Publisher's Note: MDPI stays neutral with regard to jurisdictional claims in published maps and institutional affiliations.

Copyright: (C) 2021 by the authors Licensee MDPI, Basel, Switzerland. This article is an open access article distributed under the terms and conditions of the Creative Commons Attribution (CC BY) license (https:// creativecommons.org/licenses/by/ $4.0 /)$.

\begin{abstract}
A global expansion in public and private initiatives seeks to strengthen the link between traditional products and sustainable development by creating a niche in the market for these products. Relevant examples are the Geographical Indications and the Slow Food Presidia models. This paper compares both types of Origin Food Schemes (OFS) to disclose the main commonalities and differences in their institutionalization, and their complex outcomes on cultural biodiversity (CB), which is a major concern for the sustainability of rural communities. We used underpinning knowledge dynamics as an analytical lens through the cross-comparison of ethnographic findings collected in four case studies of origin cheeses located in France, Italy and Morocco. Our findings suggest that OFS have high potential to defend CB because of their collective and context-dependent approaches. We argue that knowledge and practices mobilized in OFS are the result of power relations and confrontations among local actors, and show how four identified tensions between different forms and types of knowledge differently shape food culture, food technique, perceptions, and representations. In conclusion, the institutional approaches, practices and knowledge dynamics compared in this analysis show six effective ways to link OFS and CB, facilitating the trajectory toward sustainable development.
\end{abstract}

Keywords: origin food; slow food; geographical indications; cultural biodiversity; heritage; knowledge; specifications; cheese

\section{Introduction}

Food and place of origin are intimately, but often superficially, linked in the contemporary transnational global market, which generally lacks identity, uniqueness and authenticity [1,2]. Although the practice of naming food after places is widespread and has a long history, product differentiation based on origin is increasingly addressing growing market niches in industrialized nations using organized qualification strategies [3,4]. Origin food qualification has emerged as a new institutional trend since the 1980s, becoming a relevant asset in the European model of agriculture [5]. In addition to such governmental strategic effort, 'new forms of (semi-) private regulation of these markets' are emerging, led by non-governmental organizations (NGOs) through the implementation of voluntary labeling schemes that address the decreasing direct state regulation of agricultural markets [6]. In the private sector, private label brands and supermarket chains adopt customized 'source of origin' branding to differentiate high quality products.

The phenomenon of collective place-based narratives and labels is exemplified by Geographical Indications (GIs), the most widespread and well-known type of recognition given to origin food, and by Slow Food Presidia. Presidia, which currently number 600 in 78 countries, are projects developed by the Slow Food international movement since 
its inception in 2000 to protect food at risk of disappearing through market creation and cultural valorization. Strengthening producers' organization and establishing stronger links between producers and consumers are the key strategies to preserve local traditional breeds, varieties, landscapes and practices in Presidia. To a certain extent, GIs also aim at preserving traditional products and their valuable contribution to sustainable development by creating for them a specific segment of the market.

However, despite the environmental and cultural claims attached to both GIs and Presidia, authors increasingly question their effectiveness in defending the 'inextricable link' between biological and cultural diversity, such as language, cultural values, traditional knowledge and practices $[7,8]$, hereby defined as cultural biodiversity $(\mathrm{CB})[9,10]$. Agricultural, domesticated, biodiversity, 'is essentially a product of the intervention of man in the ecosystems' through 'the cultural processes, the knowledge, practices, and agricultural innovations' that farmers have developed [11]. Some authors question the impact of GIs on CB when specialty foods, in particular from the Global South, become global commodities and local farmers risk losing control of their local resources and food sovereignty in favor of private interests. This situation represents a threat to local skills, genetic resources and, more generally, sustainable development [12-14]. Other authors have pointed out the contradictory discourse and practice of the Slow Food movement, revealing hidden implications of consumer action with respect to environmental and cultural crises [15-19]. Indeed, it seems that, beyond the programmatic aim of preserving $C B$ underlying both schemes, their effects on knowledge (production and transmission) and practices in the local community still need to be fully unpacked. Moreover, we observe a gap in the literature on the extensive comparison between different OFS, except in political and legal frameworks [20], and on how local actors understand them.

Building on empirical studies conducted on mountain origin cheeses, this paper intends to establish a comparison of two Origin Food Schemes (OFS), namely the Geographical Indication and the Slow Food Presidia models, concerning two determining factors: i) their modalities of institutionalization and ii) their knowledge dynamics. Considering that narratives not only describe but create reality [21], and that all types of knowledge are not neutral but are shaped and reproduced by power [22], we hypothesize that knowledge and practices mobilized in OFS are the result of power relations and confrontations. Local actors, on all levels, have agency in appropriating, interpreting and reinventing different forms of knowledge. Thus, taking $\mathrm{CB}$ as a revealing element of such knowledge dynamics allows for an insightful comparison of the two OFS.

This paper first introduces the conceptual framework underpinning this study and discloses the existing interaction between OFS and CB. This is followed by the presentation of our research area (rural mountain areas in France, Italy and Morocco) and methods. The main findings help conceptualize the effects of OFS on CB, establishing a comparison between the two systems by focusing on their knowledge dynamics. Finally, this paper discusses underpinning power relations and the potential of OFS to influence $\mathrm{CB}$, which helps to develop a framework for assessing which conditions are needed to have positive effects while guaranteeing the potential for sustainable development.

\section{Conceptualizing the Effects of OFS on Cultural Biodiversity}

\subsection{Preliminary Definition and Relevance of OFS}

In this paper, we will refer to GIs-including both Protected Geographical Indications (PGI) and the Protected Designation of Origin (PDO)—and Slow Food Presidia as Origin Food Schemes (OFS), i.e., public or private initiatives which recognize and valorize origin food based on the assumption that the unique quality of a product is determined by its geographical origin, with specific reference to the local biological resources, history and know-how, and whose intrinsic qualities could not be duplicated anywhere else on Earth. The expression Origin Food Scheme recalls that of Quality Scheme, which enjoyed widespread political use from the 1992 reform of the Common Agricultural Policy (CAP), 
shifting the focus of the EU from price support to rural development, and refers to policies on geographical indications, traditional food recipes, organic production [23].

OFS differ from other market tools meant to differentiate quality food on the basis of its origin, namely institutional or collective place brands, or trademarks referring to a place $[24,25]$. Although all these initiatives have a clear economic scope, some crucial points exclusively characterize GIs and Presidia:

- Production is locally rooted. A multilevel connection to the territory is guaranteed, not only to the place of production;

- The link between 'product and place' derives from a specific process of production, local knowledge and culture embodying production and consumption habits;

- Food quality is well known, documented and historically linked to a geographical region that makes the product different from another produced elsewhere;

- The production process is a collective heritage that belongs to the producers' community. Specifications are public and fully accessible;

- GIs and Presidia cannot be sold or licensed and are generally not subject to renewal [26].

This paper focuses only on the schemes referring to the geographical environment of the place of origin, where geographical environment is understood to include inherent natural and human factors, such as climate, soil quality and local know-how. We chose two of most relevant examples of OFS, which share a common stage, i.e., the recognition and promotion of origin food, but have highly different foundations: GIs are legal and marketing tools designed by the EU (GIs), whereas Slow Food Presidia are initiatives that are framed by civil society (Slow Food Presidia).

The adopted territorial multi-stakeholder notion of OFS is reminiscent of that of food systems, which has been widely addressed by the scientific literature [27-29]. Moreover, building on Rangnekar [30], OFS are simultaneously considered as multifunctional social constructs addressing a diversity of environmental, marketing, social and cultural scopes, and as complex systems in which environment, food products, people and their institutions, know-how, food habits and social relationships combine within a territory [29]. This definition of OFS, thus, brings together both legal and marketing aspects, people, practices, collective representations and local governance.

\subsection{Multifunctionality of OFS: Cultural Biodiversity at Stake}

OFS are supposed to have multiple functions and outcomes, attracting increasing worldwide attention. Primarily, OFS create market value for origin foods by mobilizing consumers' trust in the uniqueness and authenticity of local food. Moreover, OFS contribute to the fair trade of foods, protecting consumers and producers from the potentially misleading marketing of conventional foods. In addition, OFS generate significant environmental, social and cultural outputs [31-33].

Expanding upon this last aspect, the establishment of OFS aims to link food with a territory and a community. Such initiatives tend to 're-localize' and 're-embed' [34] food into social, cultural, and environmental relations. A collective process of inception and governance, 'the creation of historical and cultural ties', and 'the promotion of sustainable practices' [32] shape a multidimensional link of OFS to a territory. This suggests that they may provide a significant contribution to food security and the maintenance of local foodways [31], influence the economic development of a specific area and be used as tools for local development $[17,35,36]$. Furthermore, they may transform local cultural and biological resources in collective heritage, i.e., a common good with an economic value [37-40], or be used as a 'remarkable opportunity to resist the erasure of place and participate in social movements of place' by protecting community assets [30].

Recent decades have been notably characterized by the erosion of agricultural biodiversity and loss of local food distinctiveness [27]. In such a general context, policy makers, social movements and scholars have increasingly looked at the impact of OFS on biodiversity, in which the preservation of cultural systems is as important as the conservation 
of the associated biological resources [10]. Origin foods are the result of the 'co-evolution of plants, animals and people connected through a culture of techniques and know-how embedded in agronomic and agro-industrial practices [...] constructing the agro-food cultural heritage of a territory' [41]. Such knowledge and practices are essential to the identity, reputation, marketing and (re)production of origin food. Specific habits of consumption, taste preference, memories, imageries and social organization also contribute to construct such CB [9].

Promoters of OFS in general, and GIs and Presidia in particular, claim that they enhance $\mathrm{CB}$ while encouraging sustainable development (Figure 1). Thus, OFS are considered among heterogeneous legal, political and economic responses to the erosion of $\mathrm{CB}$, with a special concern in countries of the Global South $[10,42]$. The general assumption they make - and hereby discussed-is that OFS give market and cultural recognition of specific local resources and practices, and CB is thereby defended.

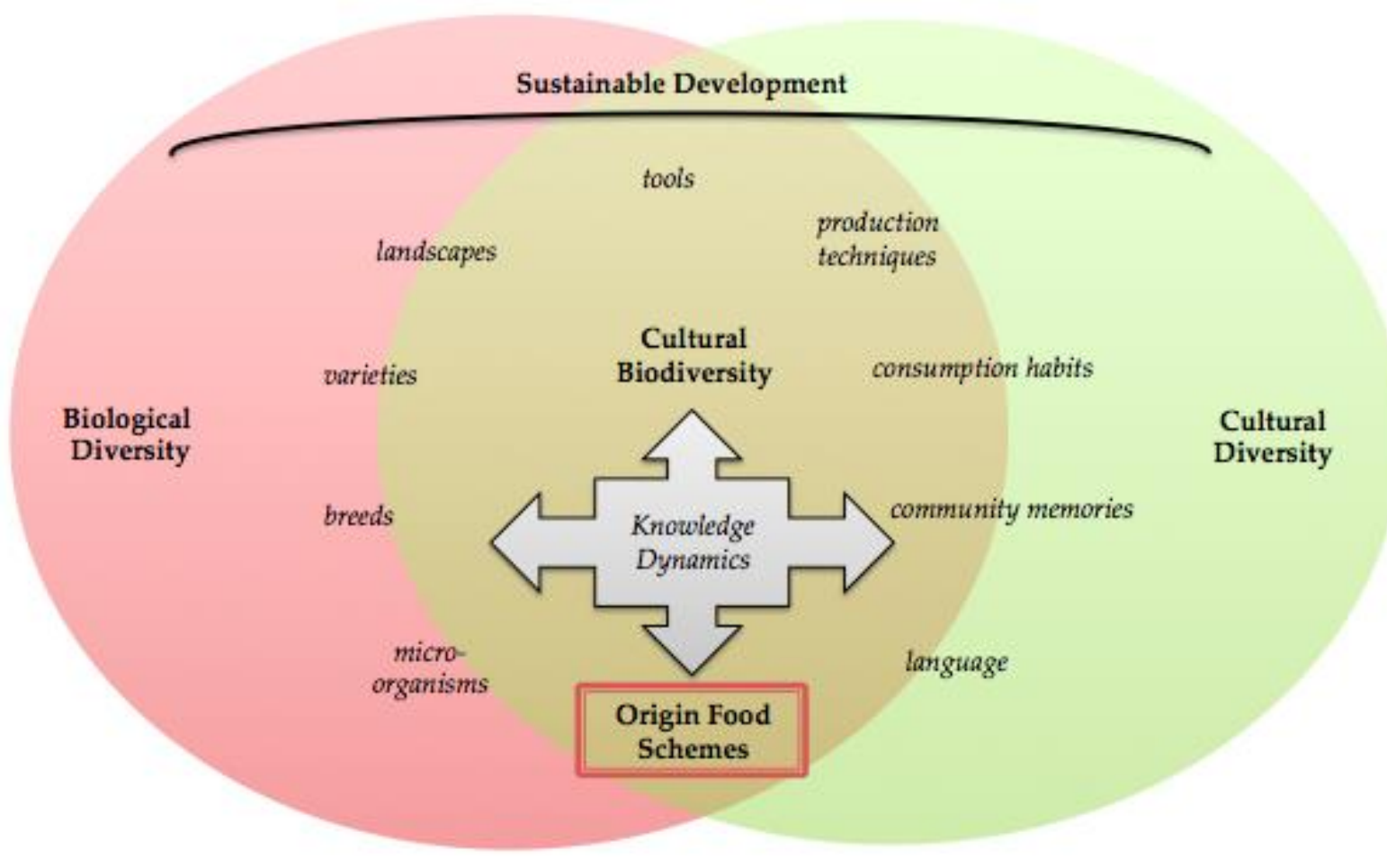

Figure 1. Understanding the relationship between OFS and CB.

In this paper, we consider that the development of OFS is the result of complex dynamics, where discontinuities (or gaps) between policy (and the related discourse) and practice can be observed and analyzed in relation to the inherent differences of the collective initiatives of OFS. Thus, with a comparative approach, OFS are hereby explored for their institutional framework, underpinning motivation and values and knowledge dynamics, which are understood by looking at the changing status of local knowledge. In particular, an exploration and confrontation of knowledge dynamics are used as a prism for explaining both the diversities between different OFS and the complex and context-dependent nature of OFS, as well as on the outcomes on traditional foods and associated CB.

\section{Materials and Methods}

\subsection{Case Studies: Mountain Cheeses in France, Italy, and Morocco}

The research was conducted on four origin cheese involved in a studied OFS (GI or Presidium), located in three countries (France, Italy and Morocco), following the case studies methodology [43]. In these three countries, GIs and the Slow Food movement are particularly relevant and in development. The three are located in the Mediterranean, 
where a large majority of OFS are produced and marketed and, meanwhile, such originbased production systems are currently under threat due to the expansion of the dominant industrial production system [44].

Regarding GIs, the three countries of the study share a similar regulatory framework, and this allowed limiting and narrowing down the elements of comparison in our analysis. The three countries are members of the World Trade Organization (WTO) and, in the framework of The Agreement on Trade-Related Aspects of Intellectual Property Rights (TRIPs), have included GIs as part of their IP legislation, following a sui generis approach (rather than a trademark approach) that establishes GIs as a specific IP category. In France and Italy, the concept of GI has a long history, and plays a major role in these markets [45-47]. Morocco, conversely, is a Southern country experiencing a rapid increase in GIs. In the last decade, the Moroccan government has outlined national policies to foster GIs as a rural development tool, under the framework of the Plan Maroc Vert, i.e., the 2008 national policy plan on agriculture meant to frame structural reforms to ensure food security and economic growth $[25,48,49]$.

Regarding Slow Food, Italy - the country of origin of the movement-is key in understanding of the development of Presidia. Italy alone accounts for $50 \%$ of total Presidia worldwide. France is third in the number of Slow Food Presidia and it was among the first countries to launch the project after Italy. Finally, Morocco has a growing exposure to the Slow Food movement and is one of the African countries where the movement is increasingly supported by national and local institutions.

This research focuses on mountain origin cheeses for two sets of reasons.

(i) First, the link between mountain cheese and cultural biodiversity is inextricable and multifaceted. As Bérard and Marchenay [9] suggest, cheese is 'at the crossroad of biology and culture. [...] The cheesemaking systems unite countless practices and forms of knowledge from all domains of living organisms, including plants, animals, and micro-organisms'. Similarly, mountains are recognized as storehouses of CB $[50,51]$. OFS may have a crucial role in mountain cultural biodiversity, from ecosystems to local knowledge. For instance, OFS may contribute to the conservation of mountain pastures, local flora and fauna, including breeds, and the conservation of microbial organisms, especially in cheeses. From the point of view of local knowledge, mountain cheese is highly linked to the conservation of ancestral production techniques, traditional tools and materials.

(ii) Next, our focus is motivated by the worldwide economic relevance of the market of specialty cheese. Cheese is the second niche product in terms of trade, after wine, and has a long history of regulation of origin [52]. For instance, in France, the National Committee for Cheese GIs (French acronym CNAOF) was created in 1955. Like wine, cheese can be shipped long distances and has access to distant markets. Moreover, the positive economic outputs of the development of OFS are particularly crucial in mountains, which are recognized as marginal areas where conventional productive agriculture cannot be competitive [32,51].

The selection of case studies was based on the geographic and economic production setting, the size of the supply chain, the motives for initiating the OFS and the type of OFS. With the aim of diversity in these criteria, the following were selected: one GI (Chefchaouen goat cheese, Morocco), one Presidium that partially overlaps with a GI (Béarn mountain cheese and Ossau-Iraty, France) and one GI that is also a Presidium (Piacentinu Ennese sheep cheese, Italy) (Table 1). We considered the two cases located in the French Pyrenees separately because the trajectories of the two OFS are divergent, often in opposition, and the products underpinning the two OFS highly differ. In the case of Piacentinu Ennese, the Presidium and the GI overlap (the one prepares and complements the other), and thus are considered as a single case study. 
Table 1. Case studies for a broad spectrum of experiences.

\begin{tabular}{|c|c|c|c|c|}
\hline & Ossau Iraty & Béarn Mountain Cheese & Chefchaouen Goat Cheese & Piacentinu Ennese \\
\hline Initiative & GI since 1980 & Presidium since 2008 & GI since 2011 & $\begin{array}{l}\text { Presidium since 2011; } \\
\text { GI since } 2013 .\end{array}$ \\
\hline Location & Béarn and Pays Basque, France & Béarn Valleys, France & Chefchaouen province, Morocco & Sicily, Italy \\
\hline OFS Promoters & $\begin{array}{l}\text { Syndicat de Défense AOP } \\
\text { OSSAU-IRATY }\end{array}$ & $\begin{array}{c}\text { Association des Eleveurs Transhumants } \\
\text { des } 3 \text { Vallées Béarnaises (AET3V), Slow } \\
\text { Food Convivium }\end{array}$ & $\begin{array}{l}\text { Association nationale ovine et } \\
\text { caprine (ANOC) }\end{array}$ & $\begin{array}{l}\text { Consorzio di tutela Formaggio } \\
\text { Piacentinu Ennese }\end{array}$ \\
\hline $\begin{array}{c}\text { Members entitled to use } \\
\text { the OFS (2018) }\end{array}$ & $\begin{array}{c}\text { 1340, of which } 1160 \text { are ewe milk } \\
\text { suppliers, } 156 \text { on-farm producers, and } \\
21 \text { dairies and affineurs, } 3 \text { milk collectors }\end{array}$ & $\begin{array}{l}51 \text { (ewe, cow, goat) shepherds and } \\
\text { cheesemakers }\end{array}$ & 40 goat milk suppliers, 1 dairy & $\begin{array}{l}7 \text { cheesemakers producing and/or } \\
\text { transforming ewe milk }\end{array}$ \\
\hline Production volume (2018) & 4359 tons & Approx. 60 tons & Approx. 64 tons & 35 tons \\
\hline Market & National distribution & $\begin{array}{l}\text { Local consumers, tourists, specialty } \\
\text { shops in the major French cities }\end{array}$ & $\begin{array}{l}\text { Local consumers, tourists, } \\
\text { restaurants, supermarkets in the } \\
\text { major Northern Moroccan cities }\end{array}$ & $\begin{array}{c}\text { Local consumers, specialty shops in } \\
\text { Northern Italy }\end{array}$ \\
\hline
\end{tabular}




\subsection{Data Collection: An Ethnographic Enquiry}

Each case study was approached through two periods of fieldwork conducted between December 2013 and August 2015, and follow up field visits were performed in 2016 and 2017. The corpus of data, Table 2, was collected through ethnographic methods and iteration, including:

(i) Participant observation in the production and market of origin cheese, including on-farm cheesemaking with selected producers, farmers markets and Slow Food events, to unfold the practical experience of different communities and the actor's point of view;

(ii) Semi-structured interviews with producers, technicians, trainers and public administrators to determine the governance ideal type of both Presidia and GIs (motivation associated to launch of the initiative, actors' involvement and management system), and the most relevant challenges they are facing (estimated results and pitfalls);

(iii) Informal interviews with producers, consumers and cooks designed along 3 axes: background (context, motivation associated to the initiative, estimated results), discourses on $C B$ (understanding and value), practices of $C B$ (learning experiences, production practices, changes);

(iv) Written sources that helped to design and develop the field analysis and the following data analysis.

Table 2. Ethnographic data collection.

\begin{tabular}{ccccc}
\hline & Ossau Iraty GI & $\begin{array}{c}\text { Béarn Mountain } \\
\text { Cheese Presidium }\end{array}$ & $\begin{array}{c}\text { Chefchaouen Goat } \\
\text { Cheese GI }\end{array}$ & $\begin{array}{c}\text { Piacentinu Ennese } \\
\text { Presidium and GI }\end{array}$ \\
\hline Participant observation & 4 weeks & 4 weeks & 8 weeks & 6 weeks \\
Semi-structured interviews & 10 & 10 & 13 & 20 \\
Informal interviews & 28 & 32 & 38 & 33 \\
Written sources & reports from agricultural institutions, NGOs, leaflets, farmers' websites, local press \\
\hline
\end{tabular}

These mainly ethnographic data are extensively presented and discussed in previous works $[53,54]$. The present paper results from the cross-comparison of such multi-site information to reflect on each case study from a broader perspective and to allow for the development of an explanatory model. An interpretative approach $[55,56]$ allows us to consider how local knowledge dynamics are connected with national/global processes and clarify OFS outcomes in relation to CB.

\subsection{Analytical Choices: Institutionalization and Knowledge Dynamics}

In order to explore the complex issue of the link between CB and OFS, we made two main analytical choices. First, the institutionalization of OFS was explored though an in-depth analysis of the academic and gray literature on OFS, which comprises institutional and promotional material, including websites and press. Crucial commonalities and differences of the two OFS were compared on two levels, i.e., (i) the institutional framework that originated and framed the two types of OFS and (ii) the motivation and values underpinning the two models.

Next, an analysis of knowledge dynamics underpinning both OFS was performed as a prism to understand the link between such collective experiences and CB. Knowledge dynamics are understood by looking at the changing status of local knowledge and practices resulting from the development of an OFS. Four main areas of tension were thus identified (Figure 2). Based on that, we showed gaps or discontinuities between (i) tacit or lay knowledge and knowledge that is codified, especially in product specifications [5]; (ii) knowledge related to food production and that related to consumption; (iii) knowledge that is narrated, belonging to the realm of discourse and knowledge that is experienced; and (iv) the memory of a product and its established reputation as a traditional product. 


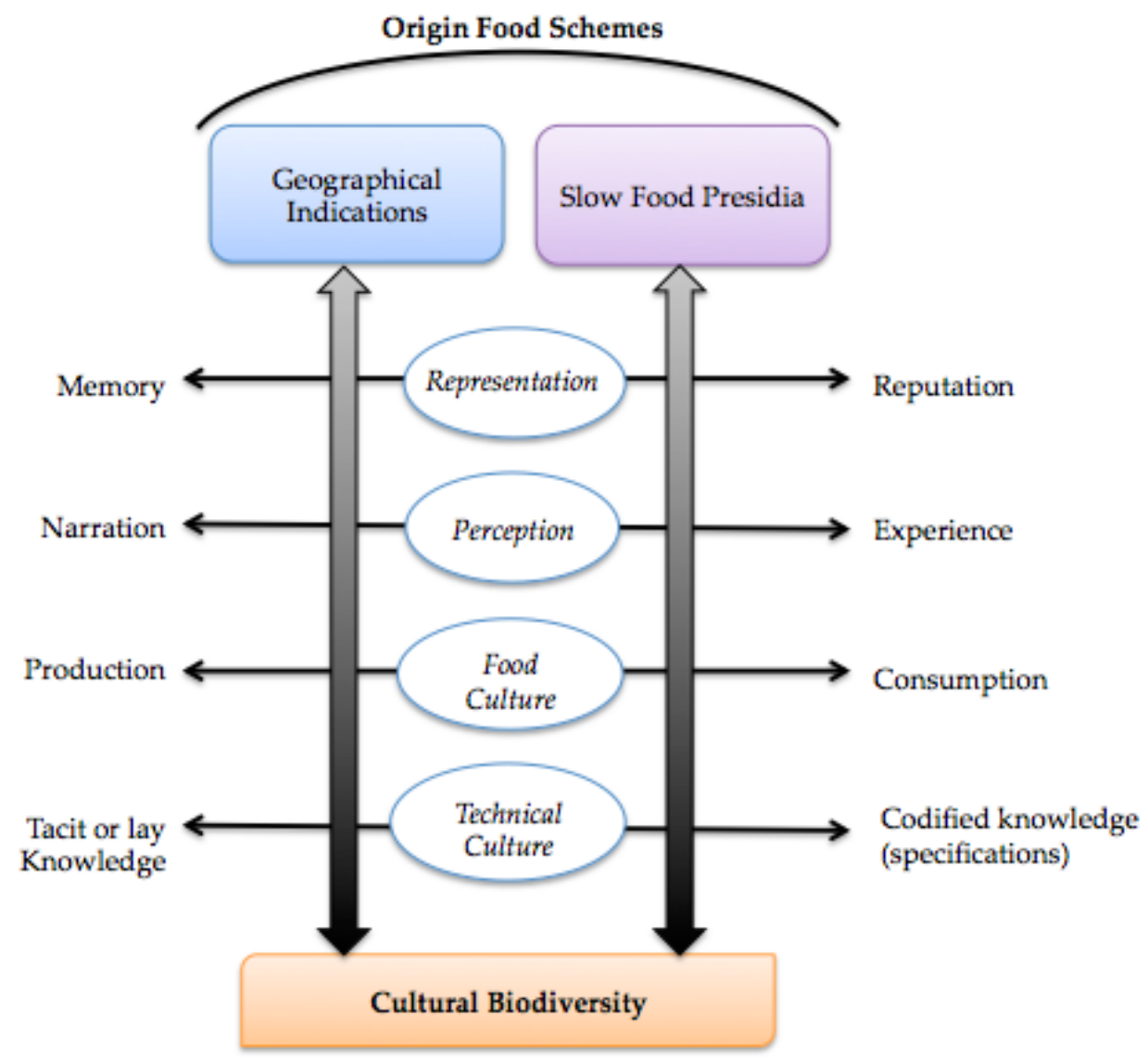

Figure 2. The four areas of tension explaining knowledge dynamics.

\section{Results}

\subsection{Contrasting OFS Models: Institutional Features and Associated Values}

A first level of comparison (or contrast) relies on the institutional features of both schemes (see Table 3). GIs are mainly considered a public right and are owned and/or enforced by states or parastatal entities on behalf of producer groups leading the initiative, in conformity with specifications (collective right of use) [24]. In the case of Presidia, Slow Food owns the project (and the Presidia brand, as in the case of Italy and Switzerland), and gives the right to use the name of the Presidium to individual producers (individual right of use). A major difference is the form of protection provided by the two OFS: legal collective protection in the case of GIs versus activism based on personal engagement in Slow Food [20]. These different forms of protection are mirrored by a different control system, which is managed by a third party in the case of GIs, and is based on producers' motivation and participatory methods in Presidia.

On a second level of comparison that relates to values and motives, our results show that both OFS aim at increasing competitiveness in a market niche by justifying added value through the valorization of local biological and cultural resources (Table 4). Both OFS mobilize CB by referring to similar 'ontologies of nature' [21], based on their market value. On one hand, to different degrees, GIs, and PDOs in particular, insist on the link between $C B$ and the uniqueness of products and their cultural and geographical environment as main attributes of quality. Traditional knowledge and practices prove the authenticity of the link between a place and the product, protecting against imitations. Moreover, the collective selection and recognition of traditional practices to be included in the specifications strengthen the GI farmers' organization. 
Table 3. GIs and Presidia institutional features.

\section{Geographical Indications}

Paris Convention 1883, incorporated into TRIPS 1994

Creation

\section{Diffusion}

Status

Entitlement

Duration

Delivery

Applicant

Approved by a public procedure by the State or, in the EU, by the European Commission

TRIPS, 84 countries developed a sui generis syste

Collective IP rights owned by states or a parastatal entity

Exclusive use of the protected origin food name (with exceptions)

Unlimited in time

Producers organization formally recognized

Self-regulation carried out by the GI operators, internal controls carried out by the

Control governing body of the GI and external controls carried out by third party control bodies, according to the control plan defined by each GI.

Enforcement State enforcement. In EU, the European Court of Justice resolves conflicts among member states, under the TRIPS framework.

\section{Slow Food Presidia}

2000

78 countries

Projects; Slow Food Presidium brand in Italy, Switzerland, and for coffee, owned by Slow Food association

Use of the reference Slow Food Presidium, but no exclusive use of the origin food name Until the objectives are met or conditions change Slow Food Foundation for Biodiversity

The Foundation assesses the launch following a request from national or local Slow Food associations or, when network is weak, by NGOs or public institutions

Collective self-regulation, including checks by Slow supporters, 'participatory certification', no third-party enforcement.

The Slow Food Foundation resolves conflicts. 
On the other hand, Slow Food Presidia value traditional knowledge per se, and emphasize the rareness of engendered products, based on the best practices that exist in a territory, in an economy of singularity [59]. Communication about endangered foods is thus focused on the exceptionality of local traditional practices and the moral goodness related to the effort of preserving $\mathrm{CB}$ in all its forms, from landscapes to breeds, from techniques to memories of a community.

Table 4. GIs and Presidia main motives and values.

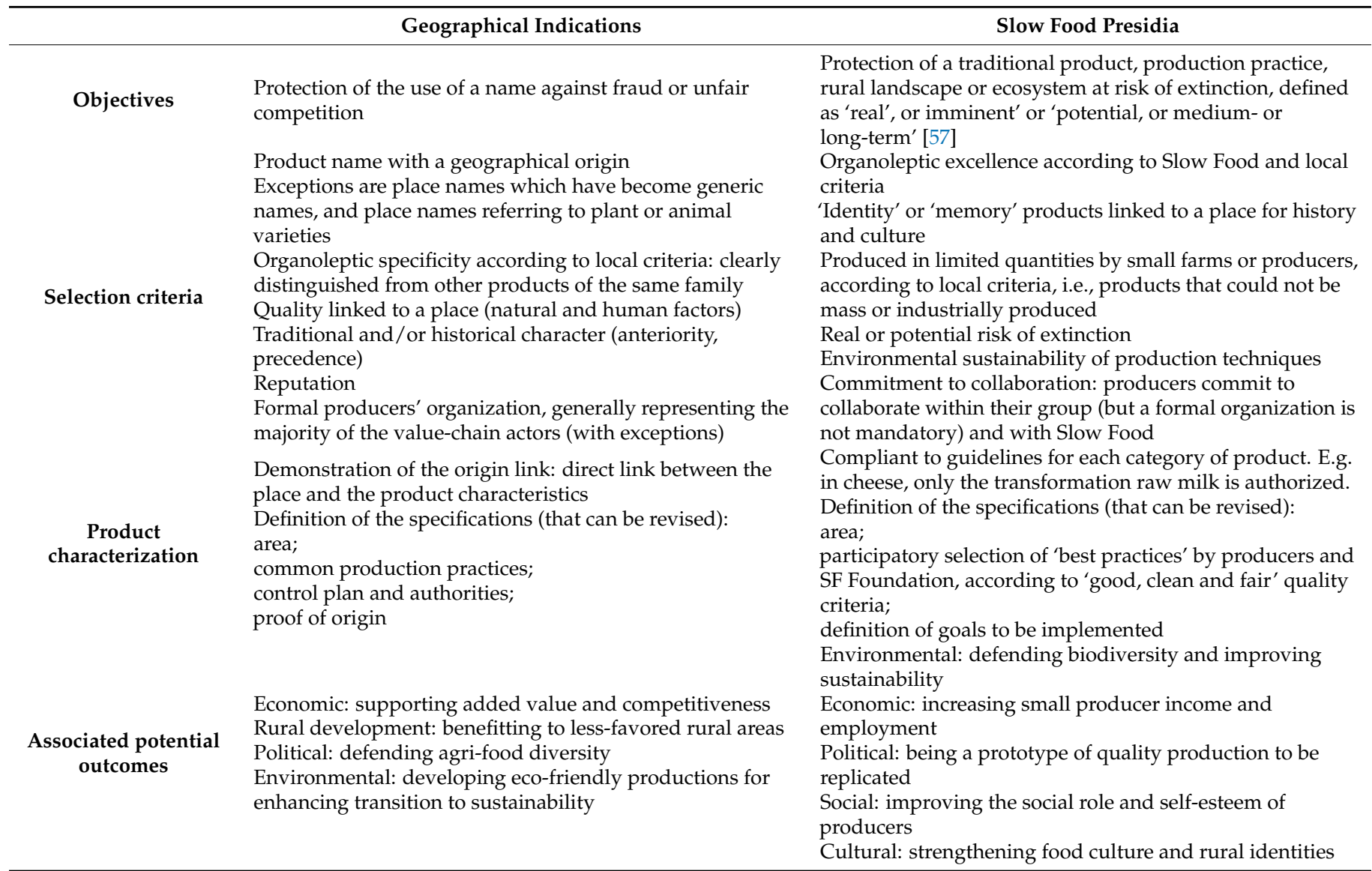

Created from multiple sources author's research, [60].

Our case studies revealed a divergence of the two OFS in different contexts and countries (Table 1). In Ossau-Iraty GI, large dairies collaborate with an increasing number of on-farm cheesemakers to promote a mass-produced local cheese labeled with images of mountains and local breeds, whereas, for Béarn Mountain cheese, traditional shepherds united and gained visibility with Slow Food to distinguish the traditional type of Pyrenees cheese made in high-mountains from that made on the lowlands, often by industrial processes. In Chefchaouen, a top-down initiative promotes an imported style of cheese in a governmental strategy of rural development that tends to exclude several local actors. Finally, in Piacentinu Ennese, the initiative of a few cheesemakers paved the way for the creation of the Presidium, and then for the recognition of a GI, both which aim to add value to an historical cheese on the verge of disappearance. We will further analyze our case studies on the basis of knowledge dynamics.

\subsection{Knowledge Dynamics at a Glance}

The collected findings expose the different knowledge dynamics that characterize the GI and Slow Food Presidia models; although, on the ground, differences are less clear-cut than expected. 


\subsubsection{Technical Culture: Gap between Tacit and Codified Knowledge}

In both GIs and Presidia, traditional knowledge enters a process of 'heritage making', starting from the identification of intangible cultural heritage and ending with its promotion. 'Heritage making' results in gaps between tacit and codified knowledge that can be understood in two complementary ways (Figure 3).

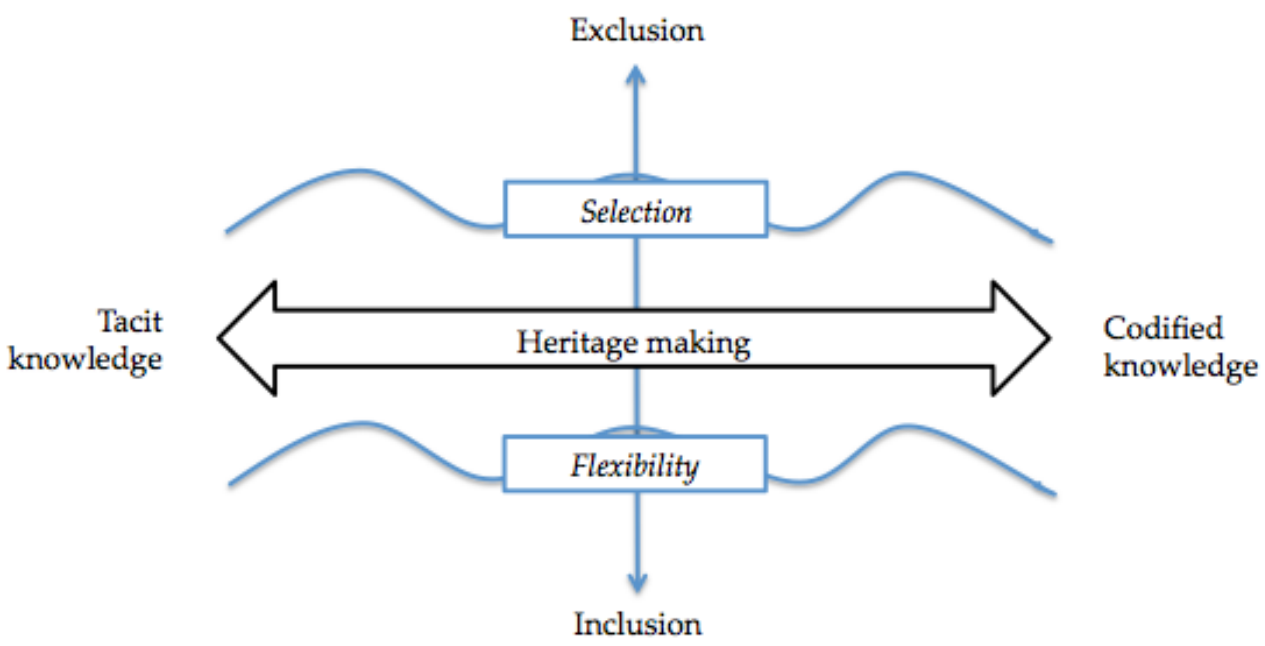

Figure 3. Heritage making results in complementary gaps in the technical culture.

On one hand, this means that OFS force choices about which knowledge and practices will enter the 'heritage making' process and which will be excluded. This selection happens according to context-dependent rationales, starting from the motivation of OFS promoters to the bargaining power along OFS development. For instance, in the case of the Béarn Mountain cheese Presidium, only a few elements are selected for the construction of the origin cheese: transhumance to high mountain pastures and daily processing of raw milk without the addition of starters. These minimal criteria are highly exclusive and contribute to building a heritage cheese that is rare and valuable. Conversely, the similar OssauIraty GI invokes different choices: only the use of ewe milk from autochthonous breeds is authorized and marketed, and the production process is highly detailed to define an easy to identify cheese. More drastically, in Chefchaouen, specifications, established in collaboration with a ministerial technical committee, made mandatory practices that tend to compromise CB (e.g., use of imported goat breeds, mandatory milk pasteurization and use of artificial rennet instead of goat and vegetable rennet, exclusion of traditional practices of salting and packaging).

On the other hand, existing gaps between tacit and codified knowledge mean that OFS regulate few aspects of food knowledge, leaving many elements open to determination and recreation by individual actors. In the same example of Béarn mountain cheese, the defense of the highly demanding practice of transhumance prevails: the choice about the type/size of the cheese and the species (ewe, cow, or goat) are open, as well as the choice of breeds; however, in practice, only rustic autochthonous breeds have adapted to the steep mountain pastures. This allows for a great diversity of cheeses. The Presidium comprises the old-style mixed cow-ewe cheese, which is, in turn, excluded from Ossau-Iraty by the French National Institute for Quality and Origin (INAO) because its 'mixed' character is considered to be too difficult to control and subject to seasonal variation. The Presidium also includes fresh goat lactic cheese that does not belong to local food habits, with a controversial approach to heritage. Conversely, in Ossau-Iraty, milk pasteurization is allowed and, thus, practices regarding the management of fresh milk differ highly among actors in terms of milk collection, stock, thermic treatment and use of starters. Similarly, the Piacentinu Ennese specifications made mandatory the use of the tina, i.e., a wooden vat whose biofilm contributes to the development of specific bacterial communities responsible 
for typical taste, but does not forbid the addition of starters. As a result, small dairies producing Piacentinu tend to add selected starters and, by doing so, 'neutralize' the desired effects of the tina.

These results shed light on specifications as a crucial element in the knowledge dynamics of OFS. In fact, specifications operate simultaneously as selection and reduction of the variety of local practices and variants [53], creating awareness among actors of the relevance of a selection of practices and determining a final result, i.e., the intrinsic and extrinsic quality attributes [61] of the product, and, more generally, the organization of the production system. All such features of specifications constantly change according to changing environment and individual trajectories.

Conversely, specifications are also a core instrument in the (re)creation of practices within a learning-by-doing process of constant adaptation [54]. This is particularly true in the case of Presidia, since Slow Food understands the design of specification as a producers' learning process and not as a rigid framework to conform to. Specifications are written by producers desiring to engage with the project, in collaboration with staff of the Slow Food Foundation for Biodiversity, to define the best existing practices and fix the target to which all producers should strive for. Thus, specifications are not, as in GIs, an entry barrier but a canvas to progressively appropriate and adapt to. In Béarn, for instance, although starters are forbidden by specifications, a small but growing number of producers are experimenting with this option as a demanding but interesting way to characterize and differentiate their product, and fit into a trend toward 'natural cheese'. In the Slow Food flexible model, it is thus possible to have producers respecting all the rules comprised in the product specifications alongside producers who do not (yet).

We thus see the definition of specifications as the result of confrontations among group members, determined by both compromise and consensus. Decisions about what elements and practices have to be included in specifications and how they have to be codified are crucial. Elements left 'uncodified' run the risk of deviant options emerging, but enhance group satisfaction over time.

\subsubsection{Food Culture: Gap between Production and Consumption Knowledge}

A second relevant gap of knowledge disclosed by this research is one between food production and food consumption. Literature agrees on the important role of OFS in reducing consumers' misinformation, correcting the information asymmetry $[62,63]$ and reducing the 'anonymity of the market' [64] which is exclusively based on profit. We found that rural knowledge cannot exist without another type of lay knowledge that is embodied by (urban) consumers in the successful alternative local configurations of food systems. The studied OFS reduce this gap in two main intertwined ways, i.e., informative labels and direct relationships (Figure 4).

First, the case studies analysis showed that, when consumers and producers lose their direct relationship, labels are drivers for knowledge and increased consumer awareness. In Europe, for over two decades, the CAP has promoted a narrative of diversity of food products, coupled with sustainability and food identity, by means of the GI model. Marketing, research and communication initiatives have supported this key competitiveness strategy for EU rural areas. Conversely, in Morocco, the attempted role of market regulation of GIs is still not recognized by local stakeholders, despite a growing institutional effort to educate consumers and producers about the advantages of the GI legal protection. Moreover, we observed a lack of trust in governmental extralocally driven initiatives, perceived as usurping local heritage and power. Nevertheless, findings from our case studies suggest that. in the European cases as well as in Morocco, institutional communication driven by GI labels alone can fail to make consumers more aware of the specific practices of production and their implications (in terms of labor, tastes and environmental outputs). Slow Food underlines that a synthetic labeling system that provides misleading or implicit information on the production practices, i.e., by allowing public consultation of specifications, is not suitable for food made with demanding traditional techniques. Thus, Slow Food developed 
'narrative labels,', i.e., back-labels that give details about the varieties or breeds, cultivation techniques, processing, place of origin and animal welfare. These labels provide a tool for community building, based on storytelling, pictures of the producer and of the place of origin.

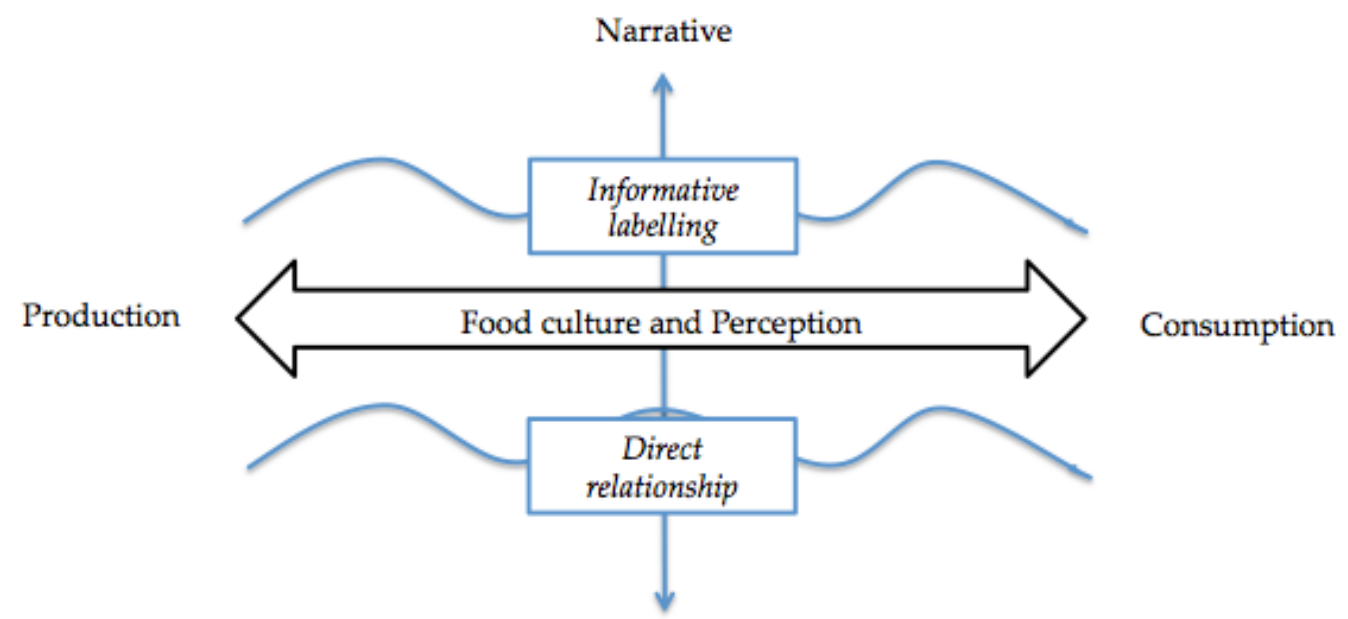

Awareness

Figure 4. Tensions between food cultures embedded in producers and consumers.

Furthermore, OFS promote direct relationships between producers and consumers, and, by doing so, foster exchanges and creation of knowledge between them [65]. Our findings showed that GIs and Presidia can be considered 'communities of practice' which include consumers, and are strengthened by practical experiences, with different casedependent results [53]. Although sharing knowledge within a renewed network of personal and practical relationships is a main feature of both studied OFS, our results show that Slow Food surpasses the GI model in this respect for two reasons.

First, Slow Food and more than GIs, tend to operate in a 'geography of regards', where consumers and producers meet; people, with their bodies and senses, are once again part of the equation. Farmers markets (Earth Markets in Slow Food jargon) and educational programs and events for children and adults are tools to build a community where producers and buyers join in long-lasting relationships.

Second, Slow Food shapes and reproduces reciprocal knowledge communities based on an 'imagined trust.' For instance, the Italian term used to refer to the leader of a local group of Slow Food supporters, i.e., the Convivium, is 'fiduciario', where 'fiducia' means trust. 'Fiduciario' is the person who producers and consumers, i.e., the Slow Food community, rely on. Slow Food Presidia are underpinned by shared communitarian values, or 'domestic trust' [62] despite also operating beyond spatial proximity. The community of Slow Food is cosmopolitan and its network of 'imagined trust' works on an international level: Terra Madre meeting, tourism among Slow Food communities, collective action promoted by campaigns, creation of a new awareness (e.g., on the use of starters in cheesemaking) and a widespread communication effort. Internal trust is based on the manifest effort of building self-regulating communities. Conversely, in GIs consumer-producer trust is built on the establishment of external guarantees-such as those mandated by the state-which are responsible for the recognition and validation of specifications, and third-party control systems. External authorities are considered as guarantors against local collusive agreement.

\subsubsection{Perceptions: Gap between Narrative and Experience}

We found that OFS can be used as vectors of values and evaluation, easily manipulated for market purposes. In the case of Ossau-Iraty, for instance, an iconographic label was first initiated by on-farm producers to distinguish their cheese from the others. Afterwards, 
industrial producers appropriated this labeling idea and introduced a double-labeling system that was applied to on-farm and industrial Ossau-Iraty GI. However, the two labels (a frontal and an in-profile sheep head) are similar, and thus distort consumers' choices, as they tend to forget that, behind such labels, there are highly different production practices (e.g., industrial pasteurization or on-farm production methods based on traditional tools and practices) [53].

In the case of Presidia, consumers tend to accept without reflection that Presidia products are better, mainly understood as better taste, although Slow Food wants to surpass label 'aesthetic veneers' [66] and train consumers to appreciate the intrinsic quality of food. Taste Workshops aim to educate consumers' palates to a codified approach to food that is shaped by Slow Food quality values and developing strategy. For instance, we participated in a Taste Workshop in Terra Madre in 2014, which aimed to train consumers in the complexity, and thus the superiority, of Béarn Mountain cheeses produced without the addition of starters, despite the evident conventional taste defaults of these experimental cheeses, pointed out by a few cheese experts.

The examples highlight another knowledge-related gap, i.e., a gap between narrated and experimented taste (Figure 4). For instance, our interviews with local consumers suggest that a certain distance exists between the narrative of Piacentinu Ennese as a traditional mature and intense cheese and its current taste, which is much more consensual and milder than it used to be. Moreover, Ossau-Iraty is depicted as an 'ancestral product'; although traditional cheeses with pungent and old-style taste for animal are systematically discarded by the GI Taste Committee [53]. Similarly, Grasseni [67] points out that a discourse on taste diversity, and on the capacity of discerning good and complex tastes, recurs within the cheese quality schemes that she studied in the Alpine region.

Our conclusion is that all the studied experiences of OFS strengthen a system where differentiation of food is mediated by labels and told, more than experienced on a sensory basis, despite the particularly widespread effort of Slow Food to outline a food knowledge system based on a sensorial, experiential and personal approach to food and food choices.

\subsubsection{Representations: Gap between Memory and Reputation}

All the above-mentioned gaps disclosed by this research illustrate a crucial conceptual point, i.e., the ambiguity of the notion of tradition underpinning OFS that needs to be unpacked and contextualized. As Lenclud [68] suggested, tradition can refer to (i) conservation over time, (ii) a cultural message, or (iii) a mode of transmission. These three dimensions of tradition are simultaneously or alternatively mobilized by OFS actors, in their constantly negotiated qualification strategy. Crystallizations of the notion of tradition result from agreements that are situated in time and place. These agreements reveal a shared present objective or strategy more than persistence. For instance, building again on the Ossau-Iraty GI Taste Committee activity, a definition of traditional cheese taste is codified and tends to be shared by jury members, possibly with a non-local background, but this is contradictory to what is considered traditional by certain locals. The agreement on taste conformity underpinning a collective judging action reflects the desire to build a certain image of OFS cheese.

Moreover, the idea of traditional food and practices holds different meanings in different countries. In this respect, our findings show a continuum among the case studies. In one extreme, in Morocco, terroir and local know-how are hardly taken in account by OFS, despite what national regulation suggests. We witnessed instead a different organization of food-related values and meanings, focusing on the concept of beldi, i.e., made by known and trusted people in a close rural area, in opposition to industrial and anonymous production standards, roumia. Origin food, the so-called 'Produits de terroir', hardly fit the category of beldi and the related market niche. Our results suggest that the roumia Chefchaouen goat cheese corresponds instead to a governmental strategy of development based on a relatively new product, an invented tradition [69] to target wealthy city consumers and tourists. 
On the other extreme, in Italy, Piacentinu Ennese is made with wooden tools forbidden by EU regulation and, in France, Béarn mountain cheese valorizes the practice of transhumance, with daily transformation in mountain huts. The concept of 'tradition/traditional' applies there to the persistence of techniques from the past and, to a lesser extent, to a mode of knowledge transmission highly valued by locals.

Ossau-Iraty, between the extremes of the continuum, illustrates the case of a (mainly) industrial product that built upon the image of traditional mountain cheese production, allowing the combination of artisan and industrial practices, in a country where 'tradition/traditional' are important marketing attributes. It is worth noting that, under the influence of the Slow Food Presidium value of transhumance, since 2017, the use of the word 'mountain' on the label has been used to distinguish Ossau-Iraty cheese made in high mountain summer pastures.

Questioning the coherence between market and tradition reveals gaps between product image, representations and local practices. This mirrors a gap between product and reputation, in particular when long distance trade relations compromise relations based on trust. In fact, OFS address efforts to embed a product in a local context, as well as increase its value/significance in distant markets. These two apparently contradictory trends have to be understood together to reveal how CB-important for sustainable development, food security and resilience of communities - takes on new meaning when cultural and biological resources leave the locality, the identity of a community and become commercially relevant on a global scale. From this point of view, GIs are not primarily intended for local consumers, but are clearly oriented by globalized markets, where guaranteed origin becomes a benchmark that produces value. In the case of Presidia, local trade prevails, but this goes along with the search for more lucrative markets. For instance, the Salone del Gusto fair in Turin serves as a catalyst of national and international marketing opportunities endorsed by Slow Food.

\section{Discussion}

Our comparison of the institutional framework of both types of OFS demonstrates that these types of schemes offer considerable flexibility and opportunities in the recognition and valorization of traditional knowledge and, thus, of CB. In fact, OFS have a highly collective and open approach, and non-economic values and motives are intrinsically connected to market in the heritage making process.

However, differences among the two OFS should be considered to determine which is the best place-based market tool according to specific goals. The GI model attempts to hide the reduction of diversity and standardization effects generated to guarantee a certain degree of homogeneity and recognizability of products, and the collective, inclusive aspect of the initiative. Conversely, Slow Food communication aims at hiding or minimizing the market influence in consumers' eyes. The need for a traditional endangered food to be sold on the modern segmented market and, thus, to meet its quality criteria, is voluntarily underestimated.

Moreover, the OFS features and potentials vary depending on national economic and legal context. In fact, while the legal definition of GI in Italy and Morocco is almost identical to that used in France-this also applies to the large majority of sui generis GI models developed worldwide [32], its translation in practice diverges [32]. Different countries are more or less open to bottom-up initiatives in rural development [25]. In France, since the beginning of the twentieth century, producers' organizations have been highly supported by national institutions, defining an institutional space for developing origin food within a generally widespread industrialization of agriculture $[45,70]$. Local actors tend to systematically refer to the centralized state in the regulation of agriculture and food. Italy boasts a more diverse origin food landscape, characterized by persistence of traditional products and practices $[39,71]$. The governmental support to origin food initiatives is more recent, primarily based on regional institutions and dynamics, and formal initiatives outside state control have emerged [17,39]. For instance, private initiatives such as Presidia seem 
to be more successful than the GI model in Sicily, where distrust towards governmental institutions is frequent [72]. On the other extreme, in Morocco, rural development in the origin food domain is characterized by top-down initiatives for at least two reasons: the search for alternatives due to the growing competition for conventional products on European markets (and, increasingly, on the national market too), and an institutional desire to promote products from specific know-how in disadvantaged rural areas [48]. Our results show that local stakeholders insufficiently appropriate such institutional efforts. This situation seems to be intertwined with a governmental preoccupation in losing local control.

Our results suggest that such institutional features of the two OFS generate distinct problems in relation to traditional practices. In GIs, we observed the problem of access of the smallest producers and their most traditional practices, due to the barriers imposed by the OFS, e.g., safety standards and money contribution [32,70,72,73]. Conversely, regarding Presidia, practices and producers may be excluded by the Slow Food authority, according to its arbitrary judgment $[74,75]$.

\subsection{Underpinning Power Relations}

The introduction to our paper declared the underpinning goal of unpacking power in OFS knowledge dynamics. Understanding these systemic and dynamic relations of power act in the field of knowledge is key in assessing the inception and non-market related outputs of OFS.

First, our findings show that OFS are 'technologies of governmentality'. The notion of 'governmentality', formulated by Foucault [22], illustrates how states design the government of territories and populations directly (as in the case of state-owned and controlled GIs) or indirectly (through a consumer movement mainly financed by public funding). OFS contribute to limiting the ownership of a community good [75], justified by scientific rationales [76]. By doing so, OFS define, conduct and limit possibilities for action [53]. For instance, producers located outside the Piacentinu Ennese production area are excluded from the use of the traditional name of Piacentinu. Consequently, they reduce their production costs by importing cheaper saffron and pasteurizing less stringently controlled and expensive milk, as competing in the same category of product (with high quality local saffron and raw milk) without benefitting from the traditional name protected by the GI would be arduous.

Conversely, the Chefchaouen goat cheese GI threatens traditional practices, knowledge and food identities. The implementation of the GI model in Morocco is entangled with Western categories of development and transferred knowledge, coupled with a specific discourse, set of knowledge and interventions. Notions and practices of safety and productivity contribute to shaping and controlling the reality where they are applied, while devaluing and considering local practices illegal, and thus forcing them to the informal market. Such transferred discourse embodies geopolitics. This confirms, among others, Van der Ploeg's [77] work on Andean farming which shows that development programs which transfer knowledge to farmers threaten their identities, and are hidden behind a strategy of empowerment.

However, two considerations limit such critical insights into the implementation of OFS as 'technologies of governmentality'. Firstly, as Fonte [5] argues, 'to avoid a commons, a res universitatis (i.e., a thing belonging to everybody in a community) becoming res nullius (a thing belonging to nobody), it is necessary to devise protective institutions', such as the 'new regimes of regulation' described by Rose [78]. Anonymous market pressures would highly threaten mountain people's CB in absence of institutional efforts to reverse the trend. Then, recognizing that OFS are also 'technologies of governmentality' of people and territories does not exclude local agency and contestation, as our findings and ethnographic literature on cultural heritage show $[39,79]$. Cultural heritage, indeed, 'is a major social arena of struggle between individuals and groups that make use of their power relations in order to promote their particular and often divergent interests or withdraw' [76]. 
Next, findings show that OFS trajectories are influenced by a power imbalance between stakeholders and their knowledge. The negotiation of specifications is a highly controversial moment in which power relations are displayed and stronger local stakeholders can overcome and exclude marginal actors and practices.

Then, the trajectories of OFS are influenced by authorities of knowledge whose contribution is often hidden to consumers' perceptions. Our results show, for instance, that Slow Food acts as an authority, defining the framework through which (moral) qualities are valued and discarded. Taste is a crucial element upon which Slow Food has built its influential role on producers and consumers by educating palates to discriminate and justify production choices. In Ossau-Iraty, similarly, tasting panels have a crucial role in building homogeneity of tastes and practices, although not as much as in French and Italian GI wines, where annual tasting panels are mandatory to monitor the typicality of wines recognized by the same GI [80].

Finally, our findings confirm that OFS are interesting tools for reducing the asymmetry of information and the 'deskilling effects' on producers and consumers generated by the modernization of agriculture [81]. In particular, OFS include consumers as a part of the learning community and empower them, unlike labels which provide information to passive consumers, in an attempt to outline 'new ways of knowing' and generating knowledge supporting the project of creating an alternative food economy [5] (p. 5). However, our research shows that market factors provide limits to the potential of OFS to promote knowledge exchanges between producers and consumers through labels and direct relationships. Confirming Le Velley [82], we observed that, in both studied OFS, the 'promise of difference' includes narrative elements of tradition and CB. This tends to select producers sharing a trajectory, a common discourse, and consumers for whom such a trajectory is pertinent. The promise of sense-making allows products to fit into a market. However, being based mainly on information on the origin, it can also be easily manipulated for market purposes. Differentiating labels risk becoming a type of façade to manipulate how consumers interpret the quality of goods [83].

\subsection{GIs and Presidia Overlaps}

This paper contributed by outlining a frequent yet understudied situation, i.e., the coexistence of both OFS on the same (or similar) product, in the same (or similar) area. The combination and overlapping of two OFS are frequent, and several configurations are possible. Among our case studies, Piacentinu Ennese GI was launched three years after the creation of the Presidium, which served as a base for gaining visibility and gastronomic recognition at a national level, paving the way for the recognition of the 1000th European GI. Conversely, several Presidia have been launched in Europe for products that were already protected by a GI. In these cases, Slow Food considered protecting particular techniques of production or territorial borders not adequately defined by the GI. Formally, all Presidium producers must adhere to the GI, the Presidium specifications are thus an extension of the GI that stipulate more restrictive rules, and the Presidium name must correspond with that of the GI. However, when the trajectory of the Presidium and the GI are divergent, as in the case of Bitto cheese GI in the Italian Alps [84], Presidium producers exit the GI and renounce the use of the historical name.

In practice, other configurations are possible, such the one we analyzed in the French Pyrenees. The Béarn Mountain cheese was launched under the initiative of shepherds who were Ossau-Iraty GI leaders, and others who were GI opponents. Shepherds in opposition to the Ossau-Iraty GI considered it inadequate for valuing the uniqueness of mountain pastured-based production, but nevertheless worked side by side with GI leaders who were pushing for an implementation of the GI specifications favoring on-farm production over industrial production. This experience paved the way for the EU recognition of Ossau-Iraty mountain production in 2018, which was differentiated on the market [85]. However, producers belonging to the Presidium and transforming exclusively ewe-milk into traditional 'tommes' may or may not adhere to the GI. 
A final configuration of the two models was observed in Morocco, where Chefchaouen goat cheese GI mandates the use of synthetic rennet and pasteurization. Although not involved in the governmental GI initiative, Slow Food underlined its discrepancy with practices included in the GI specifications by including the traditional version of the Chefchaouen goat cheese (made with raw milk and natural rennet) in its Ark of Taste, i.e., a web catalogue of products at risk of disappearing, that could potentially become Presidia [86].

These overlaps help avoid short-cuts and reductionism but can also result in unintended consequences. Authors have emphasized risks of cognitive overload and confusion among consumers exposed to a growing number of voluntary labels [20]. However, our findings suggest that such coexistence produces a dynamic reflection in relation to $\mathrm{CB}$, in the reasons and ways to manage local resources. In Béarn, limits of the Ossau-Iraty GI in relation to traditional practices motivated the creation of two Presidia to value the mountain cheeses produced in Béarn and, six years later, also the in the Basque Country. Efforts in specific marginal resources have multiplied without undermining a collective initiative, such as the Ossau-Iraty, which has positive effects on the conservation of local breeds and pastoralism. A lack of consistency between the GI and Presidium stimulated progress in the Ossau-Iraty strategy on CB.

\section{Conditions to Maintain Cultural Biodiversity: Concluding Remarks}

Starting from the analysis of the complex implication of OFS on $\mathrm{CB}$, we now conclude regarding the potential for OFS to influence CB in order to develop a framework for assessing which conditions are needed to have positive effects, while guaranteeing the sustainable development of the initiatives.

It is widely recognized that the initiation and use of OFS are divided between the understanding and interests of different local stakeholders and institutional choices, and framed by social, technical, economic realities [87]. This study highlights the ontological dimension of CB. CB seems to be, when translating the words of Bruckmeier and Tovey [88] (p. 7) about sustainable development, a common "symbolic platform" on which the different actors can meet, using the same concepts while still following their specific aims and purposes'. Thus, we outlined an analytical approach aiming at understanding the role of OFS in maintaining CB by considering institutional discourses and local stakeholder appropriation, without searching for a unifying vision directing the production of knowledge and action.

Here, we summarize the main CB success factors that this paper disclosed. However, as a general conclusion, it became evident from this research that conditions needed for OFS to have a positive impact on CB are not crucial in every circumstance, and that both types of OFS are highly context and place dependent.

(i) Institutional awareness and commitment to value and protect $\mathrm{CB}$. The research show that the effect of OFS on CB is highly influenced by the institutional context, particularly at a national level. In Europe, GIs and Presidia have a long history and have, in recent years, included institutional concerns regarding CB and heritage. Conversely, in Morocco, the GI model has been recently initiated to answer to a demand of increased productivity in rural areas and increased safety of origin food.

(ii) Adaptive specifications. Local actors' appropriation of the goal of maintaining $\mathrm{CB}$ can be successfully reflected in the design of the specifications about production area, techniques, and final product characteristics. These elements contribute to affect the value of local resources in the supply chain and its externalities, such as the protection of the Pyrenees mountains. Conversely, the imposition of rigid barriers due to an excessively strict regulation of OFS that limit the individual possibility to progressively adapt to strict rules would limit 'adjustments and cross-fertilization' [89].

(iii) Comprehensive design of specifications. OFS cheeses are potentially interesting tools in protecting CB because they are based on complex production systems, ranging from grazing management to the choice of maturing facilities. The various resources 
make up an interdependent system and, thus, the risk of overexploiting one single resource is low. Comprehensive product specifications, as designed in several studied cases, can help to consolidate these interdependent systems over time, progressively including new practitioners.

(iv) Joint conservation initiatives on multiple resources. Although linking OFS to specific varieties or breeds in search of productivity or market demands ends in marginalizing other genetic resources, despite being biologically and culturally relevant, activating joint conservation initiatives to promote and safeguard varieties or breeds excluded from the specifications could counter the overexploitation of a single resource. This includes seed banks, botanical gardens [90] and the participation of OFS producers' organizations in a local network of actors devoted to preserving rural activities and creating added value for their region (e.g., through improved water and pesticide management and landscape planning).

(v) 'Enskilling' consumers to complement the labeling strategy. Public policies can contribute to make consumers' choices more informed about origin food CB by fostering the sharing of practices and knowledge. This state effort can be successfully complemented by consumers associations, such as Slow Food, or by producers themselves through the development of sensorial experiences such as the Cheese Route of Ossau-Iraty. Sensorial experiences are key elements in learning processes, transforming information into embodied knowledge and, possibly, a deeper awareness of complex dynamics related to CB.

(vi) Favoring local consumption and local economies. CB is rooted in place and culture and emerges in connection with local identities. Binding the OFS (also) to local markets, instead of exclusively prioritizing more appealing long distant markets, as it happens for the great majority of GIs and also for several Presidia in coffee and cocoa, for instance, should have a positive effect on $\mathrm{CB}$, understood also in relation to the diversity of consumption habits. In addition, local communities, who are the protagonists of Slow Food Presidia, besides codified norms, have an important role in enhancing CB by both preserving and generating new diversity.

We thus conclude that the confrontations of actors, underpinned by knowledge dynamics, determine the outcomes of OFS on CB, depending on the cases (potential and limits of different type of OFS, institutional context, involved actors, including consumers and societal concerns). Although a necessary standardization of know-how appears to be not fully compatible with the requirements for maintaining CB, local actors in both studied OFS and, in particular, in Presidia, have agency in appropriating, interpreting, communicating and reinventing traditional knowledge. Thus, OFS contribute to the recognition of the importance of, and the creation of communication channels for, $\mathrm{CB}$ and traditional practices, rather than 'protect' or 'fix' them.

Future research could investigate whether OFS built around mountain origin cheese, which integrates several elements of the ecosystem and landscape in their product specifications, could be a model for other products. Moreover, future research could confirm whether a more narrative, comprehensive labeling strategy would increase consumers' awareness and knowledge, particularly when the message is customized in relation to a specific audience and comes from a different cultural and productive background.

Author Contributions: Conceptualization, M.M. and C.C.; Methodology, M.M., C.C. and I.P.; Investigation, M.M.; Data Curation, M.M.; Writing-Original Draft Preparation, M.M.; Writing-Review and Editing, M.M., I.P. and F.C.; Visualization, M.M. and F.C.; Supervision, F.C., C.C. and I.P. All authors have read and agreed to the published version of the manuscript.

Funding: This work has been conducted as part of a PhD thesis project supported by the Agricultural Transformation by Innovation (AGTRAIN) Erasmus Mundus Joint Doctorate Programme, funded by the EACEA (Education, Audiovisual and Culture Executive Agency) of the European Commission. We also acknowledge the financial support of the 'Economic assessments of the sustainability of agri-food systems' project, by UNICT 2016-2018 Piano per la Ricerca. Linea di intervento 2-Seconda annualità P7/WP2 (5A722192141). 
Institutional Review Board Statement: Not applicable.

Informed Consent Statement: Informed consent was obtained from all subjects involved in the study.

Data Availability Statement: The data are not publicly available due to privacy.

Conflicts of Interest: The authors declare no conflict of interest.

\section{References}

1. Ritzer, G. The McDonaldization of Society; SAGE Publications: Thousand Oaks, CA, USA, 2013.

2. Fischler, C. The 'McDonaldization' of culture. In Food: A Culinary History from Antiquity to the Present; Montanari, M., Flandrin, J.L., Sonnenfeld, A., Eds.; Columbia University Press: New York, NY, USA, 1999; pp. 430-547.

3. Callon, M.; Méadel, C.; Rabeharisoa, V. The economy of qualities. Econ. Soc. 2002, 31, 194-217. [CrossRef]

4. Tregear, A.; Arfini, F.; Belletti, G.; Marescotti, A. Regional foods and rural development: The role of product qualification. J. Rural Stud. 2007, 23, 12-22. [CrossRef]

5. Fonte, M. Introduction: Food relocalisation and knowledge dynamics for sustainability in rural areas. In Naming Food after Places. Food Relocalization and Knowledge Dynamics in Rural Development; Fonte, M., Papadopolous, A.G., Eds.; Ashgate: Farnham, UK, 2010; pp. 1-35.

6. Renard, M.C.; Loconto, A. Competing logics in the further standardization of Fair Trade: ISEAL and the Símbolo de Pequeños Productores. IJSAF 2013, 20, 51-68.

7. Pretty, J.; Adams, B.; Berkes, F.; de Athayde, S.F.; Dudley, N.; Hunn, E.; Maffi, L.; Milton, K.; Rapport, D.; Robbins, P.; et al. How do biodiversity and culture intersect. In Proceedings of the Conference 'Sustaining Cultural and Biological Diversity in a Rapidly Changing World', New York, NY, USA, 2-5 April 2008.

8. Maffi, L. Biocultural diversity and sustainability. In The SAGE Handbook of Environment and Society; SAGE Publications: London, UK, 2007; pp. 267-277.

9. Bérard, L.; Marchenay, P. Biodiversité culturelle, productions localisées et indications géographiques. In Proceedings of the III Congreso Internacional de la Red SIAL, Universidad Internacional de Andalucía, Baeza, Spain, 18-21 October 2006.

10. King, A.B.; Eyzaguirre, P.B. Intellectual property rights and agricultural biodiversity: Literature addressing the suitability of IPR for the protection of indigenous resources. Agric. Hum. Values 1999, 16, 41-49. [CrossRef]

11. Santilli, J. Agrobiodiversity and the Law: Regulating Genetic Resources, Food Security and Cultural Diversity; Earthscan: London, UK, 2011.

12. Bowen, S.; Zapata, A.V. Geographical Indications, terroir, and socioeconomic and ecological sustainability: The case of Tequila. J. Rural Stud. 2009, 25, 108-119. [CrossRef]

13. Dutfield, G. The public and private domains: Intellectual property rights in traditional knowledge. Sci. Commun. 2000, 21, 274-295. [CrossRef]

14. Van de Kop, P.; Sautier, D.; Gerz, A. Origin-Based Products: Lessons for Pro-Poor Market Development; KIT and CIRAD: Amsterdam, The Netherlands, 2006.

15. Laudan, R. Slow Food: The French terroir strategy, and culinary modernism: An essay review. Food. Cult. Soc. 2004, 7, 133-144. [CrossRef]

16. Leitch, A. Slow food and the politics of pork fat: Italian food and European identity. Ethnos 2004, 68, 437-462. [CrossRef]

17. Siniscalchi, V. Environment, Regulation and the Moral Economy of Food in the Slow Food Movement. J. Political Ecol. 2013, 20, 295-305. [CrossRef]

18. West, H.G.; Domingos, N. Gourmandizing Poverty Food: The Serpa Cheese Slow Food Presidium. J. Agrar. Chang. 2012, 12, 120-143. [CrossRef]

19. Hall, C.M. The contradictions and paradoxes of Slow Food: Environmental change, sustainability and the conservation of taste. In Slow Tourism: Experiences and Mobilities; Fullagar, S., Markwell, K., Wilson, E., Eds.; Channel View Publications: Bristol, UK, 2012; pp. 53-68.

20. Parasecoli, F. Knowing Where It Comes from: Labeling Traditional Foods to Compete in a Global Market; University of Iowa Press: Iowa City, IA, USA, 2017.

21. Escobar, A. Whose knowledge, whose nature? Biodiversity, conservation, and the political ecology of social movements. J. Political Ecol. 1998, 5, 53-82. [CrossRef]

22. Foucault, M. Governmentality. In The Foucault Effect: Studies in Governmentality; Burchell, G., Gordon, C., Burchell, P., Eds.; University of Chicago Press: Chicago, IL, USA, 1991; pp. 87-104.

23. Becker, T.; Staus, A. European food quality policy: The importance of geographical indications, organic certification and food quality insurance schemes in European countries. Estey Cent. J. Int. Law Trade Policy 2009, 10, 111-130.

24. Grote, U. Environmental labeling, Protected Geographical Indications and the interests of developing countries. Estey Cent. J. Int. Law Trade Policy 2009, 10, 94-110.

25. Donner, M.I.M. Understanding Place Brands as Collective and Territorial Development Processes. Ph.D. Thesis, Wageningen University, Wageningen, The Netherlands, 2016.

26. Josling, T. The war on Terroir: Geographical Indications as a transatlantic trade conflict. J. Agric. Econ. 2006, 57, 337-363. [CrossRef] 
27. FAO. The state of food and agriculture 2013. In Food Systems for Better Nutrition; FAO: Rome, Italy, 2013.

28. Rastoin, J.-L.; Ghersi, G. Le système alimentaire mondial: Concepts et méthodes, analyses et dynamiques. In Collection Synthèses; Editeur Quae: Paris, France, 2010.

29. Muchnik, J. Localized Agrifood Systems: Concept development and diversity of situations. In Proceedings of the Annual Meeting of the Agriculture, Food and Human Values Society and the Association for the Study of Food and Society, Pennsylvania State College, University Park, State College, PA, USA, 28-31 May 2009.

30. Rangnekar, D. Remaking place: The social construction of a Geographical Indication for Feni. Environ. Plan. A 2011, 43, 2043-2059. [CrossRef]

31. Belletti, G.; Marescotti, A. GI Social and Economic Issues. SINER-GI WP2 Report (D2); Università di Firenze: Firenze, Italy, 2006.

32. Bowen, S. Embedding local places in global spaces: Geographical indications as a territorial development strategy. Rural Sociol. 2010, 75, 209-243. [CrossRef]

33. Vandecandelaere, E.; Arfini, F.; Belletti, G.; Marescotti, A. Linking People, Places and Products; FAO/SINERGI: Rome, Italy, 2009.

34. Polanyi, K. The economy as instituted process. In Trade and Markets in the Early Empires; Polanyi, K., Arensberg, C.M., Pearson, H.W., Eds.; Free Press: Glencoe, CA, USA, 1957; pp. 243-270.

35. Delfosse, C. La gouvernance des terroirs de production laitière et fromagère: Histoire et actualité. In La Gouvernance des Terroirs du Vin. Entre Local et Mondial, au Nord Comme au Sud; Hinnewinkel, J.-C., Ed.; Feret: Bordeaux, France, 2010; pp. 95-118.

36. Thévenot-Mottet, E. Geographical indications and biodiversity. In Agriculture, Biodiversity and Markets. Livelihoods and Agroecology in Comparative Perspectives; Lockie, S., Carpenter, D., Eds.; Earthscan: London, UK; New York, NY, USA, $2010 ;$ pp. $201-212$.

37. Van Caenegem, W.; Taylor, M. Real deal or no deal? A comparative analysis of raw milk cheese regulation in Australia and France. Int. J. Rural Law Policy 2017, 1, 1-15. [CrossRef]

38. Belletti, G.; Marescotti, A.; Sanz-Cañada, J.; Vakoufaris, H. Linking protection of geographical indications to the environment: Evidence from the European Union olive-oil sector. Land Use Policy 2015, 48, 94-106. [CrossRef]

39. Grasseni, C. The Heritage Arena: Reinventing Cheese in the Italian Alps; Berghahn Books: New York, NY, USA, 2017.

40. Brunori, G. Local food and alternative food networks: A communication perspective. Anthropol. Food 2007, 2. Available online: http:/ / aof.revues.org/index430.html (accessed on 17 November 2017). [CrossRef]

41. Sanz-Cañada, J.; Muchnik, J. Geographies of origin and proximity: Approaches to local agro-food systems. Cult. Hist. Digit. J. 2016, 5. Available online: http:/ / cultureandhistory.revistas.csic.es/index.php/cultureandhistory/article/view / 89 (accessed on 2 August 2018). [CrossRef]

42. Blakeney, M. Geographical Indications, Traditional Knowledge, expressions of culture and the protection of cultural products in Africa. In Extending the Protection of Geographical Indications; Blakeney, M., Coulet, T., Alemu Mengistie, G., Tonye Mahop, M., Eds.; Routledge: New York, NY, USA; London, UK, 2013; pp. 132-146.

43. Johansson, R. A Case Study Methodology. In Proceedings of the International Conference 'Methodologies in Housing Research', Stockholm, Sweden, 22-24 September 2003; Available online: http:/ / www.psyking.net/htmlobj-3839/case_study_methodology_rolf_johansson_ver_2.pdf (accessed on 19 March 2021).

44. Rastoin, J.L. Créer un label méditerranéen. Pour les produits agroalimentaires d'origine: Quelques justifications théoriques et empiriques. In Les Produits de Terroir, les Indications Géographiques et le Développement Local Durable des Pays MéditerranéensI; Options Méditerranéennes Série A, Séminaires Méditerranéens n. 89; Tekelioglu, Y., Ilbert, H., Tozanli, S., Eds.; CIHEAM: Montpellier, France, 2009; pp. 19-27.

45. Allaire, G.; Sylvander, B.; Belletti, G.; Marescotti, A.; Barjolle, D.; Thévenod-Mottet, E.; Tregear, A. Les dispositifs français et européens de protection de la qualité et de l'origine dans le contexte de l'OMC: Justifications générales et contextes nationaux. In Proceedings of the International Symposium 'Territoires et Enjeux du Développement Regional', Lyon, France, 9-11 March 2005.

46. INAO/CNAOL. Chiffres clés 2016 des Produits Sous Signes de la Qualité et de L'origine Produits Laitiers AOP et IGP. 2016. Available online: http:/ / inao.gouv.fr (accessed on 19 February 2018).

47. Qualivita. Food \& Wine products with Geographical Indication. In The European GI System, the Italian Model and the Case of Aceto Balsamico di Modena PGI; Fondazione Qualivita: Siena, Italy, 2017.

48. Hamimaz, R. Le développement des produits du terroir au Maroc: Quelques préalables. Opt. Méditerranéennes Sér. A 2009, 89, 271-279.

49. Akesbi, N. Une nouvelle stratégie pour l'agriculture marocaine: Le 'Plan Maroc Vert'. New Medit 2012, 11, 12-23.

50. Spehn, E.M.; Rudmann-Maurer, K.; Körner, C.; Maselli, D. Mountain Biodiversity and Global Change; Global Mountain Biodiversity Assessment: Basel, Switzerland, 2010.

51. Romeo, R.; Vita, A.; Testolin, R.; Hofer, T. Mapping the Vulnerability of Mountain Peoples to Food Insecurity; FAO: Rome, Italy, 2015.

52. Bérard, L.; Marchenay, P. Tradition, regulation and intellectual property: Local agricultural products and foodstuffs in France. In Valuing Local Knowledge: Indigenous Peoples and Intellectual Property Rights; Stabinsky, D., Brush, S., Eds.; Island Press: Washington, WA, USA, 1996; pp. 230-243.

53. Mariani, M.; Cerdan, C.; Peri, I. Origin food schemes and the paradox of reducing diversity to defend it. Sociol. Rural 2021. [CrossRef]

54. Mariani, M.; Cerdan, C.; Peri, I. Contested knowledge: Changing practices in origin food communities. Br. Food J. 2019, 121, 3011-3023. [CrossRef] 
55. Marcus, G.E. Ethnography in/of the World System: The emergence of multi-sited ethnography. Annu. Rev. Anthropol. 1995, 24, 95-117. [CrossRef]

56. Hine, C. Multi-sited ethnography as a middle range methodology for contemporary STS. Sci. Technol. Hum. Values 2007, 32, 652-671. [CrossRef]

57. Slow Food Foundation for Biodiversity. Available online: https://www.fondazioneslowfood.com/en/ (accessed on 15 February 2021).

58. OriGIn. Available online: https:/ / www.origin-gi.com/ (accessed on 15 February 2021).

59. Karpik, L. Valuing the Unique: The Economics of Singularities; Princeton University Press: Princeton, NJ, USA, 2010.

60. Peano, C.; Sottile, F. (Eds.) Slow Food Presidia in Europe: A model of sustainability. In An Assessment of the Sociocultural, Agri-Environmental and Economic Results; Report; Slow Food Foundation for Biodiversity: Bra, Italy, 2012.

61. Espejel, J.; Fandos, C.; Flavián, C. The influence of consumer degree of knowledge on consumer behavior: The case of Spanish olive oil. J. Food Prod. Mark. 2008, 15, 15-37. [CrossRef]

62. Dupuy, C.; Torre, A. Liens de Proximité et Relations de Confiance. In Proximités: Approches Multiformes; Bellet, M., Kirat, T., Largeron-Leteno, C., Eds.; Editions Hermès: Paris, France, 1998.

63. Goodman, D.; DuPuis, E.M.; Goodman, M.K. Alternative Food Networks: Knowledge, Practice, and Politics; Routledge: London, UK, 2011.

64. Fine, B. Commodity Production. In Marx's Capital; Palgrave Macmillan: London, UK, 1989; pp. 8-15.

65. Ilbery, B.; Kneafsey, M. Producer constructions of quality in regional speciality food production: A case study from South West England. J. Rural Stud. 2000, 16, 217-230. [CrossRef]

66. Murdoch, J.; Miele, M. 'Back to nature': Changing 'worlds of production' in the food sector. Sociol. Rural 1999, $39,465-483$. [CrossRef]

67. Grasseni, C. Slow food, fast genes: Timescapes of authenticity and innovation in the anthropology of food. Camb. Anthropol. 2005, $25,79-94$.

68. Lenclud, G. La tradition n'est plus ce qu'elle était.... Sur les notions de tradition et de société traditionnelle en ethnologie. Terrain Anthropol. Sci. Hum. 1987, 9, 110-123.

69. Hobsbawm, E.; Ranger, T. The Invention of Tradition; Cambridge University Press: Cambridge, UK, 2012.

70. Delfosse, C. La France Fromagère (1880-1990); La Boutique de 1'Histoire: Paris, France, 2007.

71. Fonte, M. Knowledge, food and place. A way of producing, a way of knowing. Sociol. Rural 2008, 48, 200-222. [CrossRef]

72. Lactimed. Developing the Typical Dairy Products in Sicily. Diagnosis and Local Strategies; Technical Report; University of Catania, Slow Food, ASTER, CIHEAM-IAMM: Montpellier, France, 2013.

73. Mancini, M.C. Geographical indications in Latin America value chains: A 'branding from below' strategy or a mechanism excluding the poorest? J. Rural Stud. 2013, 32, 295-306. [CrossRef]

74. Lotti, A. The commoditization of products and taste: Slow Food and the conservation of agrobiodiversity. Agr. Hum. Val. 2010, 27,71-83. [CrossRef]

75. May, S. Cheese, commons and commerce: On the politics and practices of branding regional food. Ethnol. Eur. 2013, 43, 62-77.

76. Silva, L.; Mota Santos, P. Ethnographies of heritage and power: Introduction. Int. J. Herit. Stud. 2012, 18, 1-7. [CrossRef]

77. Van der Ploeg, J. Potatoes and knowledge. In An Anthropological Critique of Development; Hobart, M., Ed.; Routledge: London, UK, 1993; pp. 209-226.

78. Rose, C. The comedy of the commons. Customs, commerce and inherently public property. Univ. Chic. Law Rev. 1996, 53, 711-774. [CrossRef]

79. Herzfeld, M. A Place in History: Social and Monumental Time in a Cretan Town; Princeton University Press: Princeton, NJ, USA, 1991.

80. Gade, D.W. Tradition, territory, and terroir in French viniculture: Cassis, France, and Appellation Contrôlée. Ann. Assoc. Am. Geogr. 2004, 94, 848-867.

81. Grimaldi, P. Food: A European culture and identity heritage. In Culture, Heritage, Identity and Food. A Methodological Approach; Grimaldi, P., Fassino, G., Porporato, D., Eds.; Franco Angeli: Milano, Italy, 2019.

82. Le Velly, R. Allowing for the projective dimension of agency in analysing alternative food networks. Sociol. Rural 2019, 59, 2-22. [CrossRef]

83. Guthman, J. Back to the land: The paradox of organic food standards. Environ. Plan. A 2004, 36, 511-528. [CrossRef]

84. Rinallo, D.; Pitardi, V. Open conflict as differentiation strategy in geographical indications: The Bitto Rebels case. Br. Food J. 2019, 121, 3102-3118. [CrossRef]

85. Marie, C.D.S.; Mariani, M.; Millet, M.; Cerdan, C.; Casabianca, F. Can raw milk cheese and pasteurised milk cheese coexist? Unthinkable or never really considered? Rev. Agric. Food Environ. Stud. 2020, 101, 287-309. [CrossRef]

86. Slow Food Foundation for Biodiversity, Chefchaouen Goat's Jben. Available online: https://www.fondazioneslowfood.com/en/ ark-of-taste-slow-food/chefchaouen-goats-jben/ (accessed on 20 September 2020).

87. Barjolle, D. Appellations d'origine contrôlée, un outil de propriété intellectuelle au service du développement rural. In Proceedings of the III Congreso Internacional de la Red SIAL, Universidad Internacional de Andalucía, Baeza, Spain, 18-21 October 2006.

88. Bruckmeier, K.; Tovey, H. Rural Sustainable Development in the Knowledge Society; Routledge: London, UK; New York, NY, USA, 2009.

89. Abarca, M.E. Authentic or not, it's original. Food Foodways 2004, 12, 1-25. [CrossRef]

90. Roussel, B.; Verdeaux, F. Natural patrimony and local communities in Ethiopia: Advantages and limitations of a system of geographical indications. Africa 2007, 77, 130-150. [CrossRef] 